\section{Weed Control in Yellow Squash Using Sequential Postdirected Applications of Pelargonic Acid}

\author{
Charles L. Webber III ${ }^{1}$, Merritt J. Taylor ${ }^{2,4}$, and James W. Shrefler ${ }^{3}$
}

AdDitional Index words. Amaranthus spinosus, crop injury, crop yield, Cucubita pepo, cutleaf groundcherry, Cyperus esculentus, Digitaria ischaemum, Physalis angulata, phytotoxicity, smooth crabgrass, spiny amaranth, yellow nutsedge

Summary. Squash (Cucurbita pepo) producers could benefit from additional herbicide options that are safe to the crop and provide effective weed control. Research was conducted in southeastern Oklahoma (Atoka County, Lane, OK) during 2010 and 2011 to determine the impact of pelargonic acid (PA) on weed control efficacy, crop injury, and squash yields. The experiment included PA applied unshielded postdirected at 5,10 , and $15 \mathrm{lb}$ /acre, plus an untreated weedy control and an untreated weed-free control. 'Enterprise' yellow squash was direct-seeded in single rows into raised beds. Weeds included smooth crabgrass (Digitaria ischaemum), cutleaf groundcherry (Physalis angulata), spiny amaranth (Amaranthus spinosus), and yellow nutsedge (Cyperus esculentus). Pelargonic acid was applied each year in mid-July and then reapplied 8 days later. The maximum smooth crabgrass control (98\%), broadleaf weed control (94\%), and yellow nutsedge control (41\%) was observed with the $15-1 \mathrm{~b} /$ acre PA treatment at 9 days after initial spray treatment (DAIT), 1 day after sequential treatment (1 DAST). Pelargonic acid at 15 $\mathrm{lb} /$ acre provided equal or slightly greater smooth crabgrass and broadleaf (cutleaf groundcherry and spiny amaranth) control compared with the 10-1b/acre application, and consistently greater control than the 5-lb/acre rate and the weedy control. Pelargonic acid was less effective at controlling yellow nutsedge than smooth crabgrass and broadleaf weeds. Yellow nutsedge control peaked at 9 DAIT (1 DAST) with 10-lb/acre PA (41\%). As the rate of PA increased from 5 to $15 \mathrm{lb} /$ acre, yellow nutsedge control also increased significantly for all observation dates, except for 28 DAIT. Increasing the PA application rate increased the crop injury rating at 1 and 3 days after each application ( 1 and 3 DAIT, 1 and 3 DAST). Maximum squash injury occurred for each application rate at 9 DAIT (1 DAST) with $4.4 \%, 8.0 \%$, and $12.5 \%$ injury for $P A$ rates 5,10 , and $15 \mathrm{lb} /$ acre, respectively. The 10-1b/acre PA treatment produced the highest squash yields (kilograms per hectare) and fruit number (fruit per hectare) compared with either the 5- or 15-1b/ acre rates, and equivalent yields and fruit number as the hand-weeded weed-free treatment. The 10-1b/acre PA rate applied in a timely sequential application has the potential of providing good weed control with minimal crop injury resulting in yields equivalent to weed-free hand-weeding conditions.

$\mathrm{P}$ roducers growing squash for markets who desire the use of more naturally occurring herbicides need alternatives that effectively provide season-long weed control. Although corn gluten meal has shown promise as an early-season preemergent herbicide in squash production, any uncontrolled weeds can cause serious yield reductions (Webber et al., 2010). In general, there are limited options for control of annual broadleaf weeds in summer squash and both organic and conventional producers would benefit from appropriate herbicides that effectively provide postemergent weed control (Kemble et al., 2013). Previous research with postemergence nonsynthetic contact herbicides in noncrop situations determined that these herbicides must be applied to very young or small weeds if acceptable weed control is expected (Webber et al., 2012a). A potential solution to this would be to increase weed control efficacy on larger weeds and decrease squash injury by using multiple or sequential postdirected herbicide applications (herbicides postdirected sprayed at the base of the crop rather than over the top).

Scythe ${ }^{\circledR}$ (Dow AgroSciences, Indianapolis, IN) is a fatty acid-based, nonselective, synthetic contact herbicide consisting of $57 \% \mathrm{PA}$ and other related fatty acids. Pelargonic acid is a fatty acid naturally occurring in many plants and animals and present in many foods (U.S. Environmental Protection Agency, 2004). Pelargonic acid injures and kills plants by destroying the cell membranes, causing rapid desiccation of plant tissues. Chloroplast bleaching is seen within a short time after application (Senseman, 2007). The primary impact is the immediate decrease in intercellular $\mathrm{pH}$ with a resulting loss of cell membrane integrity (Senseman, 2007). Although PA is not listed as a "certified organic" herbicide, it is seen as a more natural type herbicide for use in "sustainable" crop production (Webber and Shrefler, 2007).

Previous field studies determined that PA applied at 5, 10.8, and 16.7 $\mathrm{lb} /$ acre as Scythe ${ }^{\circledR}$ at 3\%, 6.5\%, and $10 \%(\mathrm{v} / \mathrm{v})$ in $100 \mathrm{gal} /$ acre was effective as a broadcast postemergence contact herbicide when applied to small annual weeds (Webber and Shrefler, 2007). Webber et al. (2012b) determined that the application volume could be reduced from 100 to 40 gal/acre in postdirected applications in spring transplanted onion (Allium сера) and maintain good weed control with $\mathrm{PA}$ applied at 5,10 , and $15 \mathrm{lb} /$ acre . Unfortunately, crop injury and significant reduction in onion yields were observed with PA application rates compared with the weed-free control.

Pelargonic acid in commercial formulations has potential as a nonselective postemergent contact herbicide for weeds in vegetable crops if application method and rate can be customized to individual crops to maintain weed control efficacy without reducing yields because of crop injury (Webber and Shrefler, 2007;

\begin{tabular}{llll}
\hline $\begin{array}{l}\text { Units } \\
\begin{array}{l}\text { To convert U.S. to SI, } \\
\text { multiply by }\end{array}\end{array}$ & U.S. unit & SI unit & $\begin{array}{l}\text { To convert SI to U.S., } \\
\text { multiply by }\end{array}$ \\
\hline 0.4047 & $\mathrm{acre}(\mathrm{s})$ & $\mathrm{ha}$ & $2.471 \mathrm{l}$ \\
0.3048 & $\mathrm{ft}$ & $\mathrm{m}$ & 3.2808 \\
3.7854 & $\mathrm{gal}$ & $\mathrm{L}$ & 0.2642 \\
9.3540 & gal $/ \mathrm{acre}$ & $\mathrm{L} \cdot \mathrm{ha}^{-1}$ & 0.1069 \\
2.54 & inch(es) & $\mathrm{cm}$ & 0.3937 \\
1.1209 & $\mathrm{lb} / \mathrm{acre}$ & $\mathrm{kg} \cdot \mathrm{ha}^{-1}$ & 0.8922 \\
28.3495 & $\mathrm{oz}$ & $\mathrm{g}$ & 0.0353
\end{tabular}


Webber et al., 2005, 2012a). Research was conducted to determine the impact of sequential postdirected applications of PA on weed control efficacy, crop injury, and yields in yellow squash.

\section{Materials and methods}

The experiments were conducted in 2010 and 2011 at the Oklahoma State University, Lane Agricultural Center, Lane, OK (lat. $34^{\circ} 17^{\prime} \mathrm{N}$, long. $95^{\circ} 57^{\prime} \mathrm{W}$ ), on a Bernow fine-loamy, siliceous, thermic Glossic Paleudalf soil. Before planting, the soil was fertilized and prepared following Oklahoma Cooperative Extension Service recommendations (Motes et al., 2008). The experiment was a randomized complete block design with five treatments and four replications repeated across 2010 and 2011 . 'Enterprise' yellow squash, a fast growing bush-type squash with a $4 \mathrm{l}$-d maturity, was direct-seeded into single rows on raised 36-inch-centered beds on 21 June 2010 and 2011. Plots consisted of four 36 -inch rows in plots 12 -ft wide by $30-\mathrm{ft}$ long. Squash plant stands were thinned to a consistent plant population of 46,650 plants/ha ( $26 \mathrm{~cm}$ between plants). Soil moisture was maintained during the experiment by rainfall supplemented with overhead irrigation for a combined total

We thank Buddy Faulkenberry, Research Technician [U.S. Department of Agriculture, Agriculture Research Service (USDA, ARS)], for his leadership, field work, and data processing; Michael Mobbs and Conner Garison, student workers (USDA, ARS), for their field work and data entry; and Tony Goodson (Oklahoma State University), Jaquie Pruit (Oklahoma State University), and Lacey Howery (Oklahoma State University) for their assistance with field work.

Mention of trade names or commercial products in this article is solely for the purpose of providing scientific information and does not imply recommendation or endorsement by the USDA. All programs and services of the USDA are offered on a nondiscriminatory basis without regard to race, color, national origin, religion, sex, age, marital status, or handicap. The article cited was prepared by a USDA employee as a part of his/her official duties. Copyright protection under U.S. copyright law is not available for such works. Accordingly, there is no copyright to transfer. The fact that the private publication in which the article appears is itself copyrighted does not affect the material of the U.S. Government, which can be freely reproduced by the public.

${ }^{1}$ Sugarcane Research Unit, U.S. Department of Agriculture, Agriculture Research Service, Houma, LA 70360

${ }^{2}$ Department of Agricultural Economics, Oklahoma State University, 1901 South 9th Street, Durant, OK 74702

${ }^{3}$ Cooperative Extension Service, Division of Agriculture Sciences and Natural Resources, Oklahoma State University, Durant, OK 74702

${ }^{4}$ Corresponding author. E-mail: merritt.j.taylor@okstate. edu. of 48 and $49 \mathrm{~cm}$ water for 2010 and 2011 , respectively.

Weed control treatments consisted of sequential applications of $\mathrm{PA}$ at 5,10 , and $15 \mathrm{lb} / \mathrm{acre}$, an untreated weedy control, and an untreated weed-free control with four replications. Weed-free plots were maintained by hand hoeing. Pelargonic acid was postdirected applied without shields [40 $\mathrm{gal} / \mathrm{acre}, 0.4 \mathrm{gal} / \mathrm{min}$ (XR8004VS nozzle; Spraying Systems, Wheaton, IL)] to the base of the squash plants on 13 July 2010 and 2011, $22 \mathrm{~d}$ after planting (DAP) and then reapplied $8 \mathrm{~d}$ later (21 July 2010 and 2011). No squash flowers were present at the first spraying, but flowering and pollination was initiated 2 to $3 \mathrm{~d}$ prior (27 to $28 \mathrm{DAP}$ ) to the sequential application (30 DAP). Although 'Enterprise' yellow squash has a bush-type growth habit, the lower leaves were inadvertently sprayed during both applications, and lower flowers and small fruit $(<8 \mathrm{~cm})$ were sprayed at the sequential application. At the time of initial applications, smooth crabgrass was 8 to $15 \mathrm{~cm}$ tall, cutleaf groundcherry was 5 to $8 \mathrm{~cm}$ tall, and spiny amaranth was 5 to $8 \mathrm{~cm}$ tall. Smooth crabgrass represented $60 \%$ of the weed cover, whereas cutleaf groundcherry and spiny amaranth represented $36 \%$ and $4 \%$ of weed cover, respectively. Yellow nutsedge represented less than $1 \%$ of the weed cover and was not yet emerged during the initial application dates. Yellow nutsedge was 5 to $10 \mathrm{~cm}$ tall at $3 \mathrm{~d}$ after the initial treatments and 10 to $15 \mathrm{~cm}$ tall at the second application date, 21 July 2010 and 2011 . Because of the delayed emergence of yellow nutsedge, only one application of PA was received by the weed.

Weed-control and crop injury (phytotoxicity) ratings were collected at $1,3,7,9,11,16,22$, and 28 DAIT (14 July to 10 Aug. 2010 and 2011). Weed control ratings represent the percent weed control for a treatment compared with the weedy control. A visual rating system of $0 \%$ to $100 \%$ was used, $0 \%$ representing no weed control and $100 \%$ representing complete weed control. The visual ratings were focused on the percentage groundcover that the weed control produced. For crop response to the treatments, a $0 \%$ to $100 \%$ visual rating system was used in which $0 \%$ represented no crop injury (necrosis) and 100\% represented crop death. The visual ratings were based on visual damage to the crop leaves. Weed control and crop injury data were converted using an arcsine transformation to facilitate statistical analysis and mean separation to normalize data within the parameters suggested by Ahrens et al. (1990). Marketable squash fruit (less than $7.5 \mathrm{~cm}$ in diameter and $20-\mathrm{cm}$ long) were harvested starting 28 July ( 34 DAP) for 10 harvests (about every other day) until 20 Aug. (60 DAP) for each year. Squash yields represent the combined weight of marketable squash fruit harvested during a growing season. All data (weed control ratings, crop injury, and fruit yields) were subjected to analysis of variance (SAS version 9.2; SAS Institute, Cary, $\mathrm{NC}$ ) and mean separation using least significant difference at $P=0.05$.

\section{Results and discussion}

There were no significant yearby-treatment interactions for weed ratings (Tables $1-3$ ), crop injury ratings (Table 4), or yield data (Table 5). Therefore, the data presented are averaged across 2010 and 2011.

WeEd CONTROL. Control of smooth crabgrass, 98\% (Table 1), broadleaf weeds (cutleaf groundcherry and spiny amaranth), 94\% (Table 2), and yellow nutsedge, $41.3 \%$ (Table 3 ), peaked at 9 DAIT (1 DAST) with the 15-lb/acre application rate. All weed control ratings across all application rates $(5,10$, and $15 \mathrm{lb} /$ acre $)$ decreased from the 9-DAIT ratings to the final weed ratings at 28 DAIT (10 Aug. 2010 and 2011) (Tables 1-3). Smooth crabgrass control decreased for the $15-\mathrm{lb} /$ acre rate at the 9-DAIT evaluation to $84 \%$ control at 28 DAIT (Table 1). Broadleaf weed control decreased for the $15-\mathrm{lb} /$ acre rate at 9 DAIT from $94 \%$ to $73 \%$ at 28 DAIT (Table 2). Yellow nutsedge control decreased for the $15-\mathrm{lb} /$ acre rate at 9 DAIT from $41.3 \%$ to $5.0 \%$ at 28 DAIT. The sequential application of PA (two applications $8 \mathrm{~d}$ apart) significantly increased smooth crabgrass and broadleaf (cutleaf groundcherry and spiny amaranth) control when PA was applied at 10 and $15 \mathrm{lb} /$ acre (Tables 1 and 2).

Yellow nutsedge plants did not emerge until after the initial PA treatments and the first weed rating evaluations [ I DAIT (Table 3)]. Avoidance of the first PA applications $(5,10$, and 
Table 1. Smooth crabgrass control as a result of sequential postdirected applications of pelargonic acid (PA) applied at 5, 10, and $15 \mathrm{lb} /$ acre in squash averaged across years in 2010 and 2011 at Lane, $\mathrm{OK}$.

\begin{tabular}{|c|c|c|c|c|c|c|c|c|}
\hline \multirow[b]{3}{*}{ Weed control treatment } & \multicolumn{8}{|c|}{ Days after initial treatment (DAIT) } \\
\hline & 1 & 3 & 7 & $9^{z}$ & 11 & 16 & 22 & 28 \\
\hline & \multicolumn{8}{|c|}{ Smooth crabgrass control (\%) } \\
\hline PA $10 \mathrm{lb} /$ acre & $84 \mathrm{~b}$ & $89 \mathrm{~b}$ & $88 \mathrm{~b}$ & $95 \mathrm{~b}$ & $89 \mathrm{c}$ & $83 \mathrm{~b}$ & $80 \mathrm{~b}$ & $82 \mathrm{~b}$ \\
\hline PA $15 \mathrm{lb} /$ acre & $89 \mathrm{~b}$ & $92 \mathrm{~b}$ & $90 \mathrm{~b}$ & $98 \mathrm{ab}$ & $95 \mathrm{~b}$ & $88 \mathrm{~b}$ & $85 \mathrm{~b}$ & $84 \mathrm{~b}$ \\
\hline Weedy control ${ }^{\mathrm{w}}$ & $0 \mathrm{~d}$ & $0 \mathrm{~d}$ & $0 \mathrm{~d}$ & $0 \mathrm{~d}$ & $0 \mathrm{e}$ & $0 \mathrm{~d}$ & $0 \mathrm{~d}$ & $0 \mathrm{~d}$ \\
\hline
\end{tabular}

${ }^{z}$ The second postdirected application was applied at 8 DAIT; 9, 11, 16, 22, and 28 DAIT also represent 1, 3, 8, 14, and 20 d after the sequential treatment, respectively. yPA was postdirected applied without shields to the base of the squash plants on 13 July 2010 and $2011,22 \mathrm{~d}$ after planting, and then reapplied $8 \mathrm{~d}$ later (21 July 2010 and $2011)$; l lb/acre $=1.1209 \mathrm{~kg} \cdot \mathrm{ha}^{-1}$

"Values in a column followed by the same letter are not significantly different at $P \leq 0.05$ least significant difference.

whe weeds in the weedy control were untreated and allowed to grow as a comparison with the other treatments.

vThe weed-free treatment involved the removal of all weeds by hand-weeding.

Table 2. Broadleaf (cutleaf groundcherry and spiny amaranth) weed control as a result of sequential postdirected applications of pelargonic acid (PA) applied at 5, 10, and $15 \mathrm{lb} /$ acre in squash averaged across years in 2010 and 2011 at Lane, OK.

\begin{tabular}{|c|c|c|c|c|c|c|c|c|}
\hline \multirow[b]{3}{*}{ Weed control treatment } & \multicolumn{8}{|c|}{ Days after initial treatment (DAIT) } \\
\hline & 1 & 3 & 7 & $9^{z}$ & 11 & 16 & 22 & 28 \\
\hline & \multicolumn{8}{|c|}{ Broadleaf control (\%) } \\
\hline $\mathrm{PA} 10 \mathrm{lb} /$ acre & $81 \mathrm{~b}$ & $85 \mathrm{~b}$ & $73 \mathrm{~b}$ & $88 \mathrm{c}$ & $75 \mathrm{c}$ & $75 \mathrm{c}$ & $68 c$ & $70 \mathrm{~b}$ \\
\hline PA $15 \mathrm{lb} /$ acre & $81 \mathrm{~b}$ & $85 \mathrm{~b}$ & $73 \mathrm{~b}$ & $94 \mathrm{~b}$ & $86 \mathrm{~b}$ & $83 \mathrm{~b}$ & $79 \mathrm{~b}$ & $73 \mathrm{~b}$ \\
\hline Weedy control ${ }^{\mathrm{w}}$ & $0 \mathrm{~d}$ & $0 \mathrm{~d}$ & $0 \mathrm{~d}$ & $0 \mathrm{e}$ & $0 \mathrm{e}$ & $0 \mathrm{e}$ & $0 \mathrm{e}$ & $0 \mathrm{~d}$ \\
\hline
\end{tabular}

${ }^{z}$ The second postdirected application was applied at 8 DAIT; $9,11,16,22$, and 28 DAIT also represent 1, 3, 8, 14, and 20 d after the sequential treatment, respectively. y $\mathrm{PA}$ was postdirected applied without shields to the base of the squash plants on 13 July 2010 and $2011,22 \mathrm{~d}$ after planting, and then reapplied $8 \mathrm{~d}$ later $(21$ July 2010 and $2011) ; \mathrm{l} \mathrm{lb} /$ acre $=1.1209 \mathrm{~kg} \cdot \mathrm{ha}^{-1}$.

'Values in a column followed by the same letter are not significantly different at $P \leq 0.05$ least significant difference.

wThe weeds in the weedy control were untreated and allowed to grow as a comparison with the other treatments.

vThe weed-free treatment involved the removal of all weeds by hand-weeding.

Table 3. Yellow nutsedge control as a result of sequential postdirected applications of pelargonic acid (PA) applied at 5, 10, and $15 \mathrm{lb} /$ acre in squash averaged across years in 2010 and 2011 at Lane, $O K$.

\begin{tabular}{|c|c|c|c|c|c|c|c|c|}
\hline \multirow[b]{3}{*}{ Weed control treatment } & \multicolumn{8}{|c|}{ Days after initial treatment (DAIT) } \\
\hline & $\overline{1^{z}}$ & 3 & 7 & $9^{y}$ & 11 & 16 & 22 & 28 \\
\hline & \multicolumn{8}{|c|}{ Yellow nutsedge control (\%) } \\
\hline PA $5 \mathrm{lb} / \mathrm{acre}^{\mathrm{x}}$ & - & $2.5 \mathrm{~d}^{\mathrm{w}}$ & $1.3 \mathrm{~d}$ & $2.5 \mathrm{~d}$ & $2.8 \mathrm{~d}$ & $1.5 \mathrm{~d}$ & $1.5 \mathrm{~d}$ & $0.3 \mathrm{c}$ \\
\hline PA $10 \mathrm{lb} /$ acre & - & $8.8 \mathrm{c}$ & $4.3 \mathrm{c}$ & $10.0 \mathrm{c}$ & $15.0 \mathrm{c}$ & $6.5 \mathrm{c}$ & $3.3 \mathrm{c}$ & $3.5 \mathrm{~b}$ \\
\hline PA $15 \mathrm{lb} /$ acre & - & $15.0 \mathrm{~b}$ & $7.5 \mathrm{~b}$ & $41.3 \mathrm{~b}$ & $36.3 \mathrm{~b}$ & $14.5 \mathrm{~b}$ & $8.3 \mathrm{~b}$ & $5.0 \mathrm{~b}$ \\
\hline Weedy control ${ }^{v}$ & - & $0 \mathrm{e}$ & $0 \mathrm{~d}$ & $0 \mathrm{e}$ & $0 \mathrm{e}$ & $0 \mathrm{e}$ & $0 \mathrm{e}$ & $0 \mathrm{c}$ \\
\hline Weed-free ${ }^{\mathrm{u}}$ & - & $100 \mathrm{a}$ & $100 \mathrm{a}$ & $100 \mathrm{a}$ & $100 \mathrm{a}$ & $100 \mathrm{a}$ & $100 \mathrm{a}$ & $100 \mathrm{a}$ \\
\hline
\end{tabular}

${ }^{2}$ Yellow nutsedge did not emerge until after the initial weed control application and the 1 DAIT evaluation.

"The second postdirected application was applied at 8 DAIT; $9,11,16,22$, and 28 DAIT also represent $1,3,8,14$, and $20 \mathrm{~d}$ after the sequential treatment, respectively.

"PA was postdirected applied without shields to the base of the squash plants on 13 July 2010 and $2011,22 \mathrm{~d}$ after planting, and then reapplied $8 \mathrm{~d}$ later $(21$ July 2010 and $2011) ; 1 \mathrm{lb} / \mathrm{acre}=1.1209 \mathrm{~kg} \cdot \mathrm{ha}^{-1}$.

"Values in a column followed by the same letter are not significantly different at $P \leq 0.05$ least significant difference.

"The weeds in the weedy control were untreated and allowed to grow as a comparison with the other treatments.

uhe weed-free treatment involved the removal of all weeds by hand-weeding.

$15 \mathrm{lb} /$ acre) clearly attributed to the very low yellow nutsedge control $(41 \%)$ at 9 DAIT with $15 \mathrm{lb} /$ acre PA. The late nutsedge emergence resulted in a competitive disadvantage with the developing crop and the other weed species. Yellow nutsedge is not easy to control with contact herbicides such as PA (Webber et al., $2012 b$ ). Therefore, if a producer is aware of a potentially severe yellow nutsedge infestation, it would be wise to delay the initial PA application until after yellow nutsedge emergence, but timed to prevent having to spray large yellow nutsedge seedlings.

SQUASH FOLIAR INJURY. Although the sequential postdirected application of PA at $15-\mathrm{lb} /$ acre rate resulted in the greatest weed control, it also produced the greatest crop injury (12.5\%) at 9 DAIT (1 DAST)
(Table 4). The sequential postdirected application on 21 July (2010 and 2011) may have resulted in not only foliar injury but also injury to the developing fruit, which would be harvested starting $7 \mathrm{~d}$ later (28 July 2010 and 2011). Injury for the 5- and $10-\mathrm{lb} /$ acre rates peaked at $4.4 \%$ and $8.0 \%$, respectively. Foliar injury did not occur with PA at $5 \mathrm{lb} /$ acre at 16 DAIT ( 8 DAST), but applying 10 and 
Table 4. Squash injury as a result of sequential postdirected applications of pelargonic acid (PA) applied at 5, 10, and 15 lb/ acre averaged across years in 2010 and 2011 at Lane, $O K$.

\begin{tabular}{|c|c|c|c|c|c|c|c|c|}
\hline \multirow[b]{3}{*}{ Weed control treatment } & \multicolumn{8}{|c|}{ Days after initial treatment (DAIT) } \\
\hline & 1 & 3 & 7 & $9^{z}$ & 11 & 16 & 22 & 28 \\
\hline & \multicolumn{8}{|c|}{ Crop injury (\%) } \\
\hline PA $10 \mathrm{lb} /$ acre & $3.5 \mathrm{~b}$ & $4.8 \mathrm{~b}$ & $2.8 \mathrm{a}$ & $8.0 \mathrm{~b}$ & $4.3 \mathrm{~b}$ & $0.5 \mathrm{a}$ & $0 \mathrm{a}$ & $0 \mathrm{a}$ \\
\hline PA $15 \mathrm{lb} /$ acre & $8.3 \mathrm{a}$ & $8.3 \mathrm{a}$ & $3.0 \mathrm{a}$ & $12.5 \mathrm{a}$ & $7.0 \mathrm{a}$ & $1.0 \mathrm{a}$ & $0 \mathrm{a}$ & $0 \mathrm{a}$ \\
\hline Weedy control ${ }^{\mathrm{w}}$ & $0.0 \mathrm{~d}$ & $0.0 \mathrm{~d}$ & $0.0 \mathrm{~b}$ & $0.0 \mathrm{~d}$ & $0.0 \mathrm{c}$ & $0.0 \mathrm{a}$ & $0 \mathrm{a}$ & $0 \mathrm{a}$ \\
\hline
\end{tabular}

${ }^{2}$ The second postdirected application was applied at 8 DAIT; $9,11,16,22$, and 28 DAIT also represent 1, 3, 8, 14, and 20 d after the sequential treatment, respectively. yPA was postdirected applied without shields to the base of the squash plants on 13 July 2010 and $2011,22 \mathrm{~d}$ after planting, and then reapplied $8 \mathrm{~d}$ later (21 July 2010 and $201 \mathrm{l}) ; \mathrm{l} \mathrm{lb} /$ acre $=1.1209 \mathrm{~kg} \cdot \mathrm{ha}^{-1}$

${ }^{x}$ Values in a column followed by the same letter are not significantly different at $P \leq 0.05$ least significant difference.

whe weeds in the weedy control were untreated and allowed to grow as a comparison with the other treatments.

The weed-free treatment involved the removal of all weeds by hand-weeding.

Table 5. Impact of sequential postdirected applications of pelargonic acid (PA) applied at 5, 10, and $15 \mathrm{lb} /$ acre on marketable squash fruit number and yield averaged across years in 2010 and 2011 at Lane, $O K$.

\begin{tabular}{lccc}
\hline $\begin{array}{l}\text { Weed control } \\
\text { treatment }\end{array}$ & $\begin{array}{c}\text { Fruit production } \\
(\text { fruit/ha })^{\mathbf{z}}\end{array}$ & $\begin{array}{c}\text { Yield } \\
\left(\mathbf{k g} \cdot \mathbf{h a}^{-\mathbf{l}}\right)^{\mathbf{y}}\end{array}$ & $\begin{array}{c}\text { Avg fruit wt } \\
(\mathbf{g} / \text { fruit })^{\mathbf{x}}\end{array}$ \\
\hline PA $5 \mathrm{lb} /$ acre $^{\mathrm{w}}$ & $23,620 \mathrm{c}^{\mathrm{v}}$ & $4,798 \mathrm{c}$ & $203 \mathrm{~b}$ \\
PA $10 \mathrm{lb} /$ acre $_{\text {PA } 15 \mathrm{lb} / \text { acre }^{\mathrm{y}}}^{55,911 \mathrm{a}}$ & $12,177 \mathrm{a}$ & $218 \mathrm{~b}$ \\
Weedy control $^{\mathrm{u}}$ & $43,354 \mathrm{~b}$ & $8,799 \mathrm{~b}$ & $203 \mathrm{~b}$ \\
Weed-free $^{\mathrm{t}}$ & $4,485 \mathrm{~d}$ & $1,051 \mathrm{~d}$ & $234 \mathrm{a}$ \\
\hline
\end{tabular}

${ }^{2}$ Marketable fruit (less than $7.5 \mathrm{~cm}$ in diameter and $20-\mathrm{cm}$ long) of 'Enterprise' yellow squash, a fast growing bushtype squash with a $4 \mathrm{l}$-d maturity, were harvested starting 28 July, $34 \mathrm{~d}$ after planting (DAP) for 10 harvests (about every other day) until $20 \mathrm{Aug}$. (60 DAP) for each year; $1 \mathrm{~cm}=0.3937 \mathrm{inch}, 1 \mathrm{fruit} / \mathrm{ha}=0.4047 \mathrm{fruit} / \mathrm{acre}$

${ }^{y}$ Squash yields represent the combined weight of marketable squash fruit harvested during a growing season; 1 $\mathrm{kg} \cdot \mathrm{ha}^{-1}=0.8922 \mathrm{lb} / \mathrm{acre}$.

${ }^{\mathrm{x}} 1 \mathrm{~g}=0.0353 \mathrm{oz}$.

"PA was postdirected applied without shields to the base of the squash plants on 13 July 2010 and 2011, 22 DAP, and then reapplied $8 \mathrm{~d}$ later (2l July 2010 and $201 \mathrm{l}$ ); l lb/acre $=1.1209 \mathrm{~kg} \cdot \mathrm{ha}^{-1}$.

"Values in a column followed by the same letter are not significantly different at $P \leq 0.05$ least significant difference.

"The weeds in the weedy control were untreated and allowed to grow as a comparison with the other treatments.

'The weed-free treatment involved the removal of all weeds by hand-weeding.

$15 \mathrm{lb} /$ acre significantly reduced phytotoxicity, $0.5 \%$ and $1.0 \%$ at 16 DAIT (8 DAST), respectively. Foliar injury did not occur after 22 DAIT (14 DAST) for any of the pelargonic application rates (Table 4).

SQUASH YIELDS. Squash treated with PA at $10 \mathrm{lb} /$ acre yielded greater $\left(55,91 \mathrm{l}\right.$ fruit/ha and $\left.12,177 \mathrm{~kg} \cdot \mathrm{ha}^{-1}\right)$ than squash treated with $\mathrm{PA}$ at $5 \mathrm{lb} /$ acre $\left(23,620\right.$ fruit/ha and $\left.4798 \mathrm{~kg} \cdot \mathrm{ha}^{-1}\right)$ and $15 \mathrm{lb} /$ acre $(43,354$ fruit/ha and $8799 \mathrm{~kg} \cdot \mathrm{ha}^{-1}$ ) (Table 5). The 5-lb/ acre rate of PA was significantly greater than the weedy control. The 10- and 15 -lb/acre rates were not significantly greater than the weed-free treatment $\left(46,942\right.$ fruit/ha and $\left.10,022 \mathrm{~kg} \cdot \mathrm{ha}^{-1}\right)$. The yield reduction for the $15-\mathrm{lb} /$ acre application rate, compared with the $10-\mathrm{lb} /$ acre rate, is consistent with the increase in crop injury observed at 9 DAIT (1 DAST) (Table 4). The yield reductions for the $15-\mathrm{lb} /$ acre application rate may also reflect an increase abortion of squash flowers or damage to small developing fruit. Although the weed-free treatment yields were not significantly lower than the $10-\mathrm{lb} /$ acre rate, the yields were numerically lower, an indication that hand hoeing may have had some detrimental impact compared with the sequential 10-lb/ acre applications during the season.

The weedy control averaged the largest fruit weight (234 g/fruit) compared with all treatments, but fruit size was offset by lower fruit number (4485 fruit/ha) and total yield (1051 $\left.\mathrm{kg} \cdot \mathrm{ha}^{-1}\right)($ Table 5$)$. The lack of weed control and the resulting weed competition reduced fruit production and the surviving fruit were greater in size.

\section{Conclusions}

The sequential application of PA at $10 \mathrm{lb} /$ acre produced good grass control $(>80 \%)$ and fair $(>70 \%)$ broadleaf control, low crop injury $(8 \%$ or less), and greater fruit production (fruit per hectare) and yields (kilograms per hectare) than either the 5- or $15-\mathrm{lb} /$ acre application rates. The 5 -lb/acre application rate provided the lowest crop injury ( $4.4 \%$ or less), but also ineffective weed control $(<70 \%)$, whereas the $15-\mathrm{lb} /$ acre application produced the best weed control, but yield decreasing crop damage. Future research should focus on reducing the impact of the PA on fruit damage and development in respect to application timing. The quick growing squash crop probably benefited from the rapid row closure, which reduced weed competition, combined with the short growing season. The research determined that a sequential postdirected application of PA at $10 \mathrm{lb} /$ acre in $40 \mathrm{gal} /$ acre could consistently produce satisfactory weed control with low crop injury to produce weed-free equivalent squash yields.

\section{Literature cited}

Ahrens, W.H., D.J. Cox, and G. Budhwar. 1990. Use of the arcsine and square root transformation for subjectively determined percentage data. Weed Sci. 38: $452-458$.

Kemble, J.M., K. Ivors, F.J. Louws, K.M. Jennings, and J.F. Walgenbach. 2013. Southeastern U.S. 2013 vegetable crop handbook. Vance Publishing, Lincolnshire, IL.

Motes, J., W. Roberts, J. Damicone, J. Edelson, and J. Duthie. 2008. Squash and pumpkin production. Oklahoma Coop. Ext. Serv. Fact Sheet HLA-6026.

Senseman, S.A. (ed.). 2007. Herbicide handbook. 9th ed. Weed Sci. Soc. Amer., Lawrence, KS.

U.S. Environmental Protection Agency. 2004. Pesticides: Regulating pesticides. 
Pelargonic acid (217500). 30 Sept. 2009. <http://www.epa.gov/pesticides/ biopesticides/ingredients/factsheets / factsheet_217500.htm>.

Webber, C.L., III and J.W. Shrefler. 2007. Pelargonic acid weed control: Concentrations, adjuvants, and application timing. Proc. 26th Hort. Ind. Show, Fort Smith, AR 5-6 Jan:145-148.

Webber, C.L., III, J.W. Shrefler, L.P. Brandenberger, and A.R. Davis. 2012a. $\operatorname{AXXE}^{\circledR}$ (pelargonic acid) and $\operatorname{Racer}^{\circledR}($ am- monium nonanoate): Weed control comparisons, p. 1-4. In: L. Brandenberger and L. Wells (eds.). 2011 Vegetable weed control studies. Oklahoma State Univ., Div. Agr. Sci. Natural Resources, Dept. Hort. Landscape Architecture, MP-162.

Webber, C.L., III, J.W. Shrefler, L.P. Brandenberger, and A.R. Davis. 2012b. Pelargonic acid as a post-directed herbicide for onions. Proc. 2012 Hort. Ind. Show, Tulsa, OK, 5-6 Jan:148-151.
Webber, C.L., III, J.W. Shrefler, and M.J. Taylor. 2010. Influence of corn gluten meal on squash plant survival and yields. HortTechnology 20:696-699.

Webber, C.L., III, J.W. Shrefler, and V.B. Langston. 2005. Weed control with pelargonic acid (2004) Lane, Oklahoma, p. 40-42. In: L. Brandenberger and L. Wells (eds.). 2004 Vegetable weed control studies. Oklahoma State Univ., Div. Agr. Sci. Natural Resources, Dept. Hort. Landscape Architecture, MP-162. 